\title{
PENGELOLAAN PERGURUAN TINGGI KEAGAMAAN ISLAM NEGERI BERBASIS SNI ISO 9001:2008
}

\author{
Subardi \\ Dosen Fakultas Tarbiyah IAIN SAS Bangka Belitung \\ subardi75@gmail.com
}

\begin{abstract}
Abstrak:
Tulisan ini berupaya menjawab permasalahan bagaimana mengelola Perguruan Tinggi Keagamaan Islam Negeri (PTKIN) berbasis ISO 9001:2008. Permasalahan menjadi penting karena di era Revolusi Industri 4.0, sumber daya manusia (SDM) yang berkualitas sudah tidak dapat ditawar-tawar lagi. Satu-satu cara untuk meningkatkan kualitas SDM itu adalah melalui pendidikan, khususnya lembaga pendidikan tinggi, termasuk di dalamnya Perguruan Tinggi Keagamaan Islam Negeri (PTKIN). Agar kualitas PTKIN tidak kalah dalam persaingan, maka pengelolaan PTKIN harus berbasis SNI ISO 9001:2008 sebagai salah satu manajemen mutu yang berprinsip pada TQM yang dalam penerapannya mendetail dan sistematis. Sistem ISO 9001:2008 merupakan sarana atau alat PTKIN untuk mencapai tujuan mutu yang diharapkan dan mampumenjawab tantangan era Revolusi Industri 4.0 saat ini. Selain itu, didalamya terdapat keharusan pengawasan mutu internal secara periodik (internal quality audit). Pada saat ini ISO 9001:2008 menjadi pilihan utama bagi lembaga pendidikan tinggi, PTKIN untuk menerapkan sistem manajemen mutu secara konsisten dan sistematis untuk tercapainya efektivitas dan efesiensi. Penerapan ISO 9001:2008 di PTKIN sangatlah penting sebagai sebuah langkah untuk mewujudkan dan memberikan tata kelola yang baik, meraih praktik pendidikan yang prima, meningkatkan kepuasan pelanggandan memberikan respon yang lebih baik pada kebutuhan industri. Motif utamayang dimiliki oleh PTKIN untuk menerapkan ISO 9001:2008 adalah sebagai langkah promosi untuk memberikan gambaran bahwa PTKIN memiliki mutu tinggi, visibilitas yang tinggi dan kredibilitas, respon pada faktor eksternal dan untuk mengembangkan sistem manajemen mutu secara keseluruhan, sehingga dapat memberikan layanan dan output terbaik yang dapat menjamin kepuasan seluruh customer dan stakeholder.
\end{abstract}

Kata Kunci: PTKIN, ISO 9001: 2008, Revolusi Industri 4.0, dan Manajemen Mutu

\section{Abstract}

This paper attempts to address the problem of how to manage the State Islamic Religious College (PTKIN) based on ISO 9001: 2008. Problems become important 


\section{Jurnal Ilmiah Sustainable}

Vo. 1. No. 1, Juni 2018, 75-92

because in the era of the Industrial Revolution 4.0, quality human resources (HR) cannot be bargained again. The only way to improve the quality of human resources is through education, especially higher education institutions, including the State Islamic Religious College (PTKIN). So that the quality of PTKIN is not less competitive with other universities in Indonesia, the management of PTKIN must be based on ISO 9001: 2008 as one of the principled quality management of TQM in detailed and systematic application. The ISO 9001: 2008 system is a means or tool of PTKIN to achieve the expected quality objectives and is able to answer the challenges of the current Industrial Revolution 4.0 era. In addition, there is a periodic internal quality audit requirement. At present ISO 9001: 2008 is the main choice for higher education institutions, PTKIN to implement a quality management system consistently and systematically to achieve effectiveness and efficiency. The application of ISO 9001: 2008 at PTKIN is very important as a step to realize and provide good governance, achieve excellent education practices, improve customer satisfaction and provide a better response to industry needs. PTKIN's main motive for implementing ISO 9001: 2008 is as a promotional step to provide an overview that PTKIN has high quality, high visibility and credibility, response to external factors and to develop an overall quality management system, so as to provide services and output the best that can guarantee the satisfaction of all customers and stakeholders.

Keyword: PTKIN, ISO 9001: 2008, Revolusi Industri 4.0, dan Manajemen Mutu

\section{A. Pendahuluan}

Era milenial atau sering juga disebut era Revolusi Industri 4.0 telah memasuki "sendi-sendi" peradaban manusia. Di era ini telah terjadi persaingan global semakin ketat di tengah derasnya perkembangan ilmu pengetahuan dan teknologi modern. Saat ini semua negara di dunia telah berlomba-lomba untuk melahirkan inovasi baru yang sangat kreatif dengan memperkuat riset dan mutu pendidikan tinggi. Di sinilah sumber daya manusia (SDM) yang memiliki kompetensi dan daya saing tinggi menjadi kunci untuk memenangkan kompetisi di era Revolusi Industri 4.0 ini. Seperti diungkapkan Menteri Riset, Teknologi dan Pendidikan Tinggi (Menristekdikti) Mohamad Nasir bahwa semua pihak harus menyikapi tantangan Revolusi 4.0 ini dengan cepat dan tepat, mulai dari pemerintah, perguruan tinggi, dunia industri dan masyarakat. "Menyediakan sumber daya manusia yang unggul adalah hal terpenting dalam menghadapi Revolusi Industri 4.0, mutu pendidikan tinggi juga harus terus ditingkatkan", 


\section{Jurnal Ilmiah Sustainable}

Vo. 1. No. 1, Juni 2018, 75-92

ungkap Menristekdikti saat memberikan Orasi IImiah dalam rangka Dies Natalis Universitas Islam Jember (1/4/2018). ${ }^{1}$

Apa yang dikatakan Menristekdikti ini mengisyaratkan bahwa tantangan sebuah negara untuk menjadi negara yang maju sudah mulai mengalami pergeseran. Artinya, negara yang maju tidak lagi diukur dari jumlah sumber daya alam yang dimiliki, tetapi dari seberapa banyak jumlah inovasi yang mampu dihasilkan yang dapat menggerakkan pertumbuhan ekonomi negara. Untuk menghasilkan inovasi dibutuhkan kualitas peneliti yang "mumpuni", baik di perguruan tinggi maupun di lembaga penelitian lainnya. Tentunya, kita tidak menghendaki SDM Indonesia kalah bersaing dengan SDM dari negara-negara lain. SDM Indonesia diharapkan tidak hanya dapat menjadi tuan rumah di negara sendiri, namun juga dapat berkiprah di dunia internasional.

Salah satu upaya meningkatkan SDM Indonesia yang berkualitas, sehingga mampu menghadapi tantangan di era Revolusi Industri 4.0, saat ini lembaga pendidikan tinggi, khususnya Perguruan Tinggi Keagamaan Islam Negeri (PTKIN) telah memasuki fase baru, yaitu suatu keadaan ruang lingkup program akademis yang dilaksanakan dalam bentuk Institut tidak sesuai lagi dan perlu dikembangkan kepada ruang lingkup program akademis yang lebih luas dalam bentuk Universitas. Konversi Institut menjadi Universitas ini sebenarnya sudah lama dirintis oleh para pendahulu pendiri IAIN. Rencana pengembangan IAIN menjadi UIN kini semakin diintensifkan. Namun bersamaan dengan itu masih terdapat berbagai kekhawatiran dari berbagai pihak dan permasalahan lainnya, yang perlu segera diatasi agar rencana konversi IAIN menjadi UIN itu dapat diwujudkan.

Perubahan itu sendiri tidaklah begitu sulit sepanjang adanya kebijakan politis dari pemegang kebijakan, dalam hal ini pemerintah. Tetapi yang amat penting dipertimbangkan adalah implikasi dari perubahan itu, antara lain; tenaga pengajar, fasilitas dan sarana, dana, konsep keilmuan, dan banyak lagi yang lain. Semuanya menunggu pematangan untuk berdirinya Universitas Islam

\footnotetext{
1"Menristekdikti: Persaingan Global di Era Revolusi Industri 4.0 Semakin Ketat". Lihat https://www.ristekdikti.go.id/menristekdikti-persaingan-global-di-era-revolusi-industri-4-0semakin-ketat-2/\#xdZjTrHYQmA2QPe7.99 $\{21$ Mei 2018, 08:20 WIB\} 


\section{Jurnal Ilmiah Sustainable}

Vo. 1. No. 1, Juni 2018, 75-92

Negeri (UIN), pembinaan dan perhatian terhadap IAIN adalah suatu keharusan. Konversi IAIN menjadi UIN mulai terealisasi pada tahun 2002 seiring diresmikannya UIN Syarif Hidayatullah di Jakarta dari semula IAIN Syarif Hidayatullah. Pada perkembangan selanjutnya hingga tahun 2017 terdapat 16 UIN baru di Indonesia, yaitu; UIN Syarif Hidayatullah, Tangerang Selatan (2002), UIN Sunan Kalijaga, Yogyakarta (2004), UIN Maulana Malik Ibrahim, Malang (2004), UIN Sunan Gunung Djati, Bandung (2005), UIN Alauddin, Makassar (2005), UIN Sultan Syarif Kasim, Pekanbaru (2005), UIN Ar-Raniry, Banda Aceh (2013), UIN Sunan Ampel, Surabaya (2013), UIN Raden Fatah, Palembang (2014), UIN Sumatera Utara, Medan (2014), UIN Walisongo, Semarang (2014), UIN Antasari, Banjarmasin (2017), UIN Raden Intan, Bandar Lampung (2017), UIN Sultan Maulana Hasanuddin, Serang (2017), UIN Sultan Thaha Saifuddin, Muaro Jambi (2017), dan UIN Mataram, Mataram (2017). ${ }^{2}$

Perubahan Perguruan Tinggi Keagamaan Islam Negeri (PTKIN), misalnya STAIN menjadi IAIN, IAIN menjadi UIN tentu saja bukan sekadar perubahan status dan penambahan sarana infrastruktur fisik semata, tetapi yang juga sangat penting adalah peningkatan kualitas Perguruan Tinggi Keagamaan Islam Negeri (PTKIN) itu. Di sinilah perlunya penerapan manajemen perguruan tinggi yang bermutu serta terakreditasinya perguruan tinggi itu sendiri. Perguruan tinggi yang bermutu dan terakreditasi harus mampu mengantarkan para lulusannya memiliki seperangkat pengetahuan, life skill (keterampilan hidup), berkarakter serta mampu menguasai dan diterima dalam persaingan dunia kerja yang semakin kompetitif atau mampu menciptakan lapangan kerja secara kreatif dan produktif.

Selaras dengan pernyataan di atas, Direktorat Jenderal Perguruan Tinggi Indonesia menyebutkan bahwa perguruan tinggi dikatakan bermutu apabila mampu menetapkan dan mewujudkan visi melalui misinya (aspek deduktif) dan perguruan tinggi tersebut mampu memenuhi kebutuhan stakeholders (aspek

${ }^{2}$ Lihat "Universitas Islam Negeri". Dalam https://id.wikipedia.org/wiki/Universitas _Islam_Negeri. $\{20$ Mei 2018, 09:01 WIB\} 


\section{Jurnal Ilmiah Sustainable}

Vo. 1. No. 1, Juni 2018, 75-92

induktif) yang berupa kebutuhan kemasyarakatan (social needs), dunia kerja (industrial needs), dan profesional (professional needs). ${ }^{3}$

Upaya meningkatkan kualitas Perguruan Tinggi Keagamaan Islam Negeri (PTKIN) adalah melalui SNI ISO 9001:2008 sebagai salah satu manajemen mutu yang berprinsip pada TQM. Sistem ini sangat populer karena penerapannya mendetail dan sistematis. Sistem ISO 9001:2008 merupakan sarana atau alat untuk mencapai tujuan mutu yang diharapkan dan mampu menjawab tantangan era Revolusi Industri 4.0 saat ini. Selain itu, didalamya terdapat keharusan pengawasan mutu internal secara periodik (internal quality audit). Pada saat ini ISO 9001:2008 menjadi pilihan utama bagi lembaga Perguruan Tinggi Keagamaan Islam Negeri (PTKIN) untuk menerapkan sistem manajemen mutu secara konsisten dan sistematis untuk tercapainya efektivitas dan efesiensi. ${ }^{4}$

\section{B. Sejarah Sistem Manajemen Mutu ISO 9001:2008}

Mungkin ada di antara kita yang mengatakan bahwa ISO merupakan singkatan dari International Organization for Standardization. Padahal ISO sebetulnya bukanlah singkatan, tetapi sebutan ISO berasal dari bahasa Yunani isos yang berarti sama. Penggunaan kata ISO agar mempermudah dalam penyebutan untuk International Organization for Standardization, hal ini berdasarkan pertimbangan beraneka ragamnya budaya dan bahasa dari negaranegara di seluruh dunia. Dengan demikian dapat dikatakan bahwa ISO merupakan sebuah organisasi organisasi bertaraf internasional yang khusus bergerak dalam bidang standarisasi.

Sama seperti halnya organisasi lainnya, ISO juga mempunyai suatu tujuan untuk mempromosikan dan mengembangkan standar-standar untuk umum yang berlaku secara internasional. Karena itu, ISO 9001:2008 merupakan model sistem jaminan kualitas dalam desain/ pengembangan, produksi, instalasi, dan pelayanan atau sering disebut dengan istilah Sistem Manajemen Mutu (SMM)

\footnotetext{
${ }^{3}$ Safrudin Aziz, Manajemen Mutu Perguruan Tinggi, Koreksi dan Implementasi, (Yogyakarta: Gava Media, 2016), hlm. 26.

${ }^{4}$ Umiyati, "Pengaruh Sistem Manajemen Mutu ISO 9001:2008 dan Partisipasi Penyusunan Anggaran Terhadap Kinerja Manajerial". Dalam Jurnal Etikonomi Vol. 14 No. 1 April, (Jakarta: Fakultas Ekonomi dan Bisnis, UIN Syarif Hidayatullah, 2015), hlm. 88. 


\section{Jurnal Ilmiah Sustainable}

Vo. 1. No. 1, Juni 2018, 75-92

ISO 9001:2008. Menurut Sugeng Listyo Prabowo ${ }^{5}$ bahwa ISO 9001 merupakan standar internasional yang mengatur tentang Sistem Manajemen Mutu (Quality Management System). Berdasarkan pengertian tersebut bisa disimpulkan bahwa ISO 9001 merupakan salah satu dari seri ISO 9000 yang mengatur tentang Sistem Manajemen Mutu, sehingga ISO 9001 sering disebut dengan Sistem Manajemen Mutu (SMM) ISO 9001.

Penggunan istilah ISO 9001 lahir kali pertama pada tahun 1987 yang dikenal dengan nama Sistem Manajemen Mutu (SMM) ISO 9001:1987. Ada tiga versi pilihan implementasi pada seri 1987 ini, yaitu yang menekankan pada aspek quality assurance, aspek quality assurance and production dan quality assurance for testing. Konsentrasi utamanya adalah inspection product di akhir sebuah proses (dikenal dengan final inspection) dan kepatuhan pada aturan prosedur sistem yang harus dipenuhi secara menyeluruh.

Pada perkembangan berikutnya, tepatnya tahun 1994, karena kebutuhan guaranty quality bukan hanya pada aspekfinal inspection, tetapi lebih jauh ditekankan perlunya proses preventive action untuk menghindari kesalahan pada proses yang menyebabkan ketidaksesuaian pada produk. Namun demikian seri 9001:1994 ini masih menganut prosedur sistem yang kaku dan cenderungdocument centre dibanding kebutuhan organisasi yang disesuaikan dengan proses internal organisasi.

Seri 9001:1994 lebih fokus pada proses manufacturing dan sangat sulit diaplikasikan pada organisasi bisnis kecil karena banyaknya prosedur yang harus dipenuhi. Karena ketebatasan inilah, maka technical committee melakukan tinjauan atas standar yang ada hingga akhirnya lahirlah revisi ISO 9001:2000 yang merupakan penggabungan dari ISO 9001, 9002, dan 9003 versi 1994. Pada seri 9001:2000, tidak lagi dikenal 20 klausul wajib, tetapi lebih pada proses bisnis yang terjadi dalam organisasi. Sehingga organisasi sekecil apapun bisa mengimplementasi SMM ISO 9001:2000 dengan berbagai pengecualian pada proses bisnisnya. Karena itu dikenalah istilah BPM atau Business Process Mapping, setiap organisasi harus memetakan proses bisnisnya dan menjadikannya bagian utama dalam quality manual perusahaan. Kendati

\footnotetext{
${ }^{5}$ Sugeng Listyo Prabowo. Implementasi Sistem Manajemen Mutu ISO 9001:2008 di Perguruan Tinggi (Guidelines IWA-2). (Malang: UIN-Malang Press,2009), hlm. 45. 80
} 


\section{Jurnal Ilmiah Sustainable}

Vo. 1. No. 1, Juni 2018, 75-92

demikian, ISO 9001:2000 masih mewajibkan 6 prosedur yang harus terdokumentasi, yaitu prosedur control of document, control of record, control of non conforming product, internal audit, corrective action, dan preventive action, yang semuanya bisa dipenuhi oleh organisasi bisnis manapun. Selanjutnya, dalam perkembangannya, seri ISO 9001:2008 lahir sebagai bentuk penyempurnaan atas revisi tahun 2000. Adapun perbedaan antara seri ISO 9001:2000 dengan ISO 9001:2008 secara signifikan lebih menekankan pada efektivitas proses yang dilaksanakan dalam organisasi tersebut. Jika pada seri ISO 9001: 2000 mengatakan harus dilakukan corrective dan preventive action. Namun demikian pada seri ISO 9001:2008 menetapkan bahwa proses corrective dan preventive action yang dilakukan harus secara efektif berdampak positif pada perubahan proses yang terjadi dalam organisasi. Selain itu, penekanan pada kontrol proses outsourcing menjadi bagian yang disoroti dalam seri terbaru ISO 9001 ini. $^{6}$

Menyimak paparan di atas dapat ditegaskan bahwa seri ISO 9001 dalam perkembangannya telah mengalami tiga kali revisi sejak pertama didirikan pada tahun 1987. Revisi pertama terjadi pada tahun 1994 yang selanjutnya seri ISO 9001 ini sering dikenal dengan nama Sistem Manajemen Mutu (SMM) ISO 9001:1994. Revisi kedua terjadi pada tahun 2000 yang selanjutnya seri ISO 9001 ini sering dikenal dengan nama Sistem Manajemen Mutu (SMM) ISO 9001:2000. Revisi ketiga terjadi pada tahun 2008 yang selanjutnya seri ISO 9001 ini sering dikenal dengan nama Sistem Manajemen Mutu (SMM) ISO 9001:2008. Secara umum tidak ada perubahan signifikan dari revisi tahun 2000 ke tahun 2008, tidak ada penambahan maupun pengurangan klausul di dalamnya.

\section{PTKIN dan SNI ISO 9001:2008}

ISO 9001:2008, sebagai standar internasional untuk sistem manajemen mutu telah menetapkan berbagai persyaratan dan rekomendasi untuk desain dan penilaian dari suatu sistem manajemen mutu. ${ }^{7}$ Namun pada dasarnya ISO 9001:2008 bukan merupakan standar produk, karena tidak menyatakan

${ }^{6}$ Wawan Setyawan. Prinsip Dasar ISO 9001:2008. (Jakarta: Universitas Mercu Buana, 2009).

${ }^{7}$ Gaspersz, V.,Manajemen Bisnis Total Dalam Era Globalisasi. (Jakarta:Gramedia Pustaka Utama, 2002). 


\section{Jurnal Ilmiah Sustainable}

Vo. 1. No. 1, Juni 2018, 75-92

persyaratan-persyaratan yang harus dipenuhi oleh sebuah produk, baik jasa maupun barang. Tetapi yang lebih ditekankan pada ISO 9001:2008pada standar sistem manajemen kualitas.

Meskipun ISO 9001:2008 bukan standar produk,tetapi bagaimanapun juga diharapkan bahwa produk yang dihasilkan dari suatu sistem manajemen kualitas internasional, akan berkualitas baik (standar).Sehingga dapat disimpulkan bahwa ISO 9001:2008merupakan prosedur terdokumentasi dan praktik-praktik standar untuk manajemen sistem. Tujuannya untuk menjamin kesesuaian dari suatu proses dan produk (barang atau jasa) terhadap kebutuhan atau persyaratan tertentu, dimana kebutuhan atau persyaratan tertentu tersebut ditentukan atau dispesifikasikan oleh pelanggan dan organisasi.

Sistem manajemen mutu merupakan suatu kegiatan terkoordinasi untuk mengarahkan dan mengendalikan organisasi dalam hubungannya denganmutu. Sistem manajemen mutu dapat dijadikan alat strategis untuk mengembangkan kinerja proses dan sumber daya dalam melakukanpeningkatan terus menerus, memberikan pelayanan prima demi kepuasanpengguna untuk mempersiapkan diri menghadapi persaingan international danmendapatkan pengakuan international terhadap proses yang dilakukan. Dalam kaitan ini tuntutan penjamin mutu melahirkan suatu standar yang lebihberorientasi kepada sistem dan proses, yaitu; Standar Manajemen Mutu. Dalam sistem manajemen mutu ISO 9001 terdapat standaroperasional prosedur (SOP), instruksi kerja (work instruction), tujuan dan sasaran mutu (quality objective) dan juga program mutu (quality program). ${ }^{8}$

Bila dilihat struktur ISO 9001:2008 yang dijadikan pedoman dalam sistemmanajemen mutu pada suatu organisasi terdiri dari 8 klausul, diantaranya: (1) ruang lingkup; (2) referensi standar; (3) istilah dan definisi; (4). sistem manajemen mutu; (5). tanggungjawab manajemen; (6). manajemen sumberdaya; (7). realisasi produk; dan (8). Pengukuran, analisa dan perbaikan. ${ }^{9}$

${ }^{8}$ Umiyati, “Pengaruh Sistem Manajemen Mutu ISO 9001:2008 dan Partisipasi Penyusunan Anggaran Terhadap Kinerja Manajerial”, hlm. 92.

${ }^{9}$ bid., hlm. 92. 


\section{Jurnal Ilmiah Sustainable}

Vo. 1. No. 1, Juni 2018, 75-92

Di dalam ISO 9001:2008 yang menjadi persyaratan hanyalah 5 klausul yaitu klausul 4: Sistem Manajemen Mutu; klausul 5: Tanggungjawab Manajemen, klausul 6: Manajemen Sumber Daya; klausul 7: Realisasi Produk; dan klausul 8: Pengukuran, Analisa dan Perbaikan. Jadi suatu organisasi yang ingin menerapkan atau ingin mendapatkan sertifikasi ISO 9001 cukup dengan menerapkan kelima pasal tersebut.

Jika dikelompokkan melalui pendekatan proses maka 5 klausul : Tanggungjawab Manajemen dan klausul: Manajemen Sumber Daya merupakan bagian dari proses perencanaan (plan); klausul 7: Realisasi Produk merupakan bagian dari Proses Melakukan (do); dan klausul 8: Pengukuran, Analisa dan Perbaikan merupakan bagian dari Proses Pemeriksaan (check) dan Proses Tindakan (Act). Integrasi proses-proses Plan-Do-Check-Act (PDCA) tersebut secara sistematik akan menghasilkan suatu pendekatan Sistem Manajemen Mutu (klausul 4) ke arah perbaikan kinerja secara berkesinambungan, ${ }^{10}$ sebagaimana digambarkan di bawah ini;

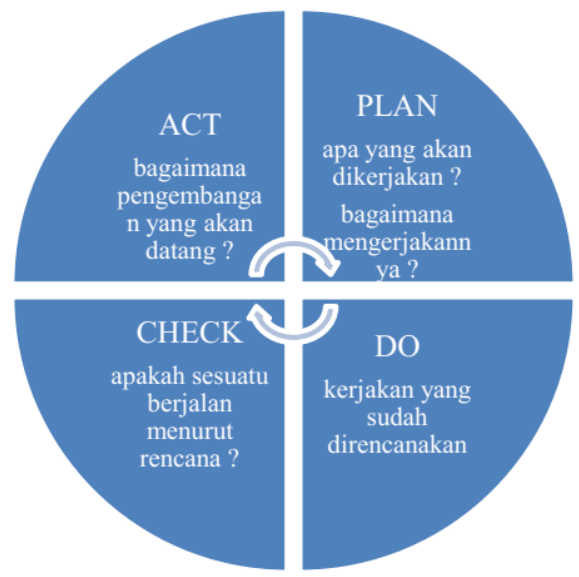

10/bid., hlm. 93. 


\section{Jurnal Ilmiah Sustainable}

Vo. 1. No. 1, Juni 2018, 75-92

Gambar 1: Landasan Proses Manajemen PDCA ${ }^{11}$

Pada proses plan, kegiatan yang dilakukan bertujuan untuk memantapkan tujuan danproses yang dibutuhkan mencapai hasil yang sesuai dengan persyaratan pelanggan dan kebijakan organisasi. Selanjutnya, pada proses do, kegiatan yang bertujuan untuk menjalankan proses. Sedangkan pada proses checkdi mana terjadi tahapan proses monitoring dan evaluasi terhadap proses dan produk yang tidak sesuai dengan kebijakan, tujuan, dan persyaratan produk serta melaporkan hasilnya. Yang terakhir proses act, yakn tahapan melaksanakan tindakan untuk proses pengembanganberkelanjutan.

Penerapan SMM ISO sebetulnya trend yang berkembang dalam dunia industri dan sudah merambah ke dunia pendidikan, termasuk perguruan tinggi sebagai kerangka sistem manajemen mutu. Hal ini disebabkan standar tersebut bersifat generik dan dapat diterapkan pada semua organisasi tanpa dibatasi oleh tipe, ukuran dan produk yang dihasilkan. Bila melihat penjelasan di atas dapat dikatakan bahwa upaya penerapan ISO 9001:2008 di PTKIN sangatlah penting sebagai sebuah langkah untuk mewujudkan dan memberikan tata kelola yang baik, meraih praktik pendidikan yang prima, meningkatkan kepuasan pelanggandan memberikan respon yang lebih baik pada kebutuhan industri. ${ }^{12}$ Motif utama yang dimiliki oleh PTKIN untuk menerapkan ISO 9001:2008 adalah sebagai langkah promosi untuk memberikan gambaran bahwa PTKIN memiliki mutu tinggi, visibilitas yang tinggi dan kredibilitas, respon pada faktor eksternal dan untuk mengembangkan sistem manajemen mutu secara keseluruhan.

Pandangan-pandangan terkait filosofi mutu PTKIN tersebut telah memberikan suatu gambaran bahwa mutu PTKIN merupakan kemampuan institusi untuk memberikan layanan dan output terbaik yang dapat menjamin kepuasan seluruh customerdan stakeholders institusi. Filosofi mutu berkembang mengikuti pemikiran dan harapan ideal masyarakat serta

\footnotetext{
${ }^{11}$ Sugeng Listyo Prabowo, Implementasi Sistem Manajemen Mutu (ISO: 9001:2008) di Perguruan Tinggi (Guidelines IWA-2), hlm. 56-57.

${ }^{12}$ Othman, R, et.al.. ISO Standard Implementation at Private Colleged: Academics and Non Academics Perspective. The 1st International Conference on Educational Reform, November 9-11, (Mahasarakham University, 2007). 


\section{Jurnal Ilmiah Sustainable}

Vo. 1. No. 1, Juni 2018, 75-92

dimaksudkan untuk memenuhi kebutuhan mereka. Dalam rangka mencapai idealisme tersebut, maka dibutuhkan manajemen yang benar dalam artian efisien dan efektif, juga dibutuhkan tipe kepemimpinan yang visioner. Di sinilah letak pentingnya penerapan SMM ISO 9001:2008 dalam membantu pengelolaan mutu PTKINyang ideal. ${ }^{13}$ Secara fungsional, PTKIN sebagai perguruan tinggi Islam di Indonesia yang pengelolaannya berada di bawah Kementerian Agama Republik Indonesia. Namun secara teknis akademik, pembinaan PTKIN dilakukan oleh Kementerian Riset, Teknologi, dan Pendidikan Tinggi Republik Indonesia (Kemristekdikti). Saat ini, di IndonesiaPTKINberjumlah 58 buah, terdiri atas 3 jenis, yakni; Universitas Islam Negeri (UIN) berjumlah 17 UIN, Institut Agama Islam Negeri (IAIN) berjumlah 34 buah dan Sekolah Tinggi Agama Islam Negeri (STAIN) berjumlah 7 STAIN.

Dalam kaitannya dengan penerapan ISO 9001:2008, PTKIN seyogyanya memberikan layanan dan output terbaik, sehingga menjamin kepuasan customer dan stakeholders. Sebab menurut Azyumardi Azra ${ }^{14}$ Setidaknya terdapat tiga peran strategis PTKIN di Indonesia. Pertama, peran struktur organisasional. Peran ini berfungsi membentuk dan menciptakan kader-kader akademis-intelektual muslim masa depan yang diharapkan mampu menjadi lokomotif pembaruan pemikiran keislaman Indonesia ke arah modernisasi perangkat-perangkat infrastruktur pendidikan Islam di masyarakat. Dengan adanya peran itu, masyarakat memiliki academic conciousness, sehingga mampu memposisi-kan dirinya dalam perhelatan sosial politik keagamaan secara moderat.

Kedua, peran sosial dan kultural. Peran ini oleh PTKIN dimediasi melalui gerakan pengabdian dan social research dengan melibatkan berbagai lapisan masyarakat. Peran ini juga tidak kalah penting, karena dengan pendekatan itu PTKIN mampu menjalin social network dengan masyarakat sebagai salah satu stakeholder serta mendorong tumbuhnya social confidence dan spirit of ethics

13 Hasyim Asy'ari, "Perbandingan Sistem Manajemen Mutu ISO 9001:2008, Standard BAN-PT dan Total Quality Management di UIN Maulana Malik Ibrahim Malang". Dalam Jurnal Pendidikan Islam, Volume IV, Nomor 1, Juni, (Yogyakarta: UIN Sunan Kalijaga, 2015), hlm. 147.

14 Azyumardi Azra, Paradigma Baru Pendidikan Nasional, Rekonstruksi dan Demokratisasi,(Jakarta: Penerbit Buku Kompas,2000), hlm. 51. 


\section{Jurnal Ilmiah Sustainable}

Vo. 1. No. 1, Juni 2018, 75-92

otonomy masyarakat yang bertumpu pada Islamic morality values, sehingga mampu menciptakan tatanan masyarakat yang beradab dan sangatlah wajar jika kemudian Indonesia menjadi center of Islamic episentrum negara muslim dunia. Atau meminjam ungkapan Daniel S. Live, ${ }^{15}$ Indonesia is the most moderate countries yang tidak hanya kokoh akan tradisi multikulturalismenya, tetapi juga memiliki komitmen yang tinggi akan tradisi keislamaannya. Wajar jika kemudian barat lebih berkiblat ke Indonesia dalam konteks kajian keislaman.

Ketiga, secara spiritual, PTKIN juga berperan dalam membentuk masyarakat agar memiliki kesadaran keagamaan (religious consiousness). Agama menjadi platform of human life agar manusia tidak terasing dengan lingkungan dan Tuhannya. Peran spiritual ini menjadi penting terutama dalam mengarungi fase era Revolusi 4.0, yang oleh Zukav ${ }^{16}$ disebutnya sebagai era blind of materialism (segala sesuatu banyak diukur oleh materi tanpa memperhitungkan kondisi psikologis manusia). Dampaknya banyak manusia yang mengalami stres dalam segala bidang kehidupan, termasuk dalam hal pendidikan. Hasil penelitian Straith Time, pada tahun 2003, ada 5\% anak Singapura menderita stres berat sebagai implikasi dari globalisasi pendidikan.

Penerapan ISO 9001:2008 pada intinya merupakan suatu standar untuk melakukan perbaikan manajemen mutu sistem pendidikan tinggi Islam di PTKIN. Sallis ${ }^{17}$ menegaskan bahwa manajemen mutu pendidikan akan sangat membantu institusi pendidikan, setidaknya untuk tiga hal penting. Pertama, manajemen mutu akan memperkuat sistem pengelolaan perguruan tinggi menjadi lebih baik. Maka dengan diterapkannya manajemen mutu, kualitas PTKIN akan menjadi lebih baik. Kedua, dengan manajemen mutu, PTKIN akan mampu menghasilkan produk pendidikan tinggi Islam yang lebih unggul dan kompetitif. Ketiga, dengan manajemen mutu, PTKIN di Indonesia akan lebih

\footnotetext{
${ }^{15}$ Bunyamin dan Alamsyah, "Manajemen Mutu Perguruan Tinggi Agama Islam Swasta". Dalam Jurnal Pendidikan Islam, Vol 28, No 2, (Bandung: UIN Sunan Gunung Djati,2013), hlm. 208.

${ }^{16}$ Ibid., hIm. 208.

${ }^{17}$ Edward Sallis, Manajemen Kualitas Total Dalam Pendidikan (Total Quality Managementin Education), Terj. Kambey Daniel C., (Manado: Program Pascasarjana Universitas Negeri Manado, 2001), hlm. 53-55.

86
} 


\section{Jurnal Ilmiah Sustainable}

Vo. 1. No. 1, Juni 2018, 75-92

established dalam menjalani kompetisi dengan pendidikan tinggi lain baik swasta maupun negeri, baik dalam skala nasional, regional maupun internasional.

Hal ini dimaksudkan agar PTKIN di Indonesia mampu berkembang dan maju sesuai dengan kebutuhan global tanpa harus mengorbankan kepentingankepentingan nasional. Pandangan futuristik tersebut merupakan sesuatu hal yang wajar mengingat internasionalisasi pendidikan tinggi di era globalisasi atau liberalisasi bermediasi melalui jalur pasar bebas yang sangat mungkin tidak hanya memberikan harapan untuk semakin survive, tetapi juga ancaman untuk semakin menghancurkan roda pendidikan tinggi suatu negara, apalagi perangkat infrastruktur PTKIN di Indonesia masih jauh standar ISO 9001:2008. Jika ini tidak diantisipasi, maka bukan kemajuan yang diperoleh, tidak mustahil PTKIN itu akan "gulung tikar" tergilas liberalisasi pendidikan tinggi.

Kesiapan mental internal PTKINmelalui standar ISO 9001:2008 serta dukungan kebijakan pendidikan nasional yang antisipatif dalam merancang kebijakan di sektornya menjadi faktor penentu langgengnya suatu PTKIN. Robertson mengatakan bahwa internasionalisasi dalam pendidikan merupakan upaya penyiapan diri dari suatu negara agar ia dapat meraih kejayaan peradaban. Namun demikian internasionalisasi pendidikan jika tidak dikelola dengan baik bisa menjerumuskan negara ke dalam lembah kehancuran. ${ }^{18}$

Dalam konteks itulah, upaya strategis peningkatan manajemn mutu PTKIN segera dilakukan secara simultan dan kontinyu. Manajemen penjaminan mutu pendidikan tinggi harus berorientasi pada pengembangan international quality academics (mutu akademis berskala internasional). Bagaimanapun juga kompetisi pendidikan tinggi di era pasar bebas menuntut adanya standar mutu pendidikan yang lebih baik, yang mampu masuk ke segmen negara mana pun karena adanya global agreement standar yang memungkinkan hal itu terjadi. Manajemen sistem pendidikan yang lebih baik tersebut akan mendorong tumbuh dan berkembangnya SDM yang akan dihasilkan oleh PTKIN di masa yang akan datang dan sekaligus membantu memposisikan Indonesia dalam

\footnotetext{
${ }^{18}$ James Ward, Reclaining International Mindset of Education in Global Era, (USAWard:Penguin Book2000), hlm. 14.
} 


\section{Jurnal Ilmiah Sustainable}

Vo. 1. No. 1, Juni 2018, 75-92

berbagai tingkat kompetisi, baik regional maupun internasional menjadi semakin baik. Tentunya kebijakan perbaikan manajemen sistem pendidikan tinggi tersebut tetap harus mempertimbangkan potensi daerah di mana PTKIN tersebut berada.

Upaya pengembangan dan peningkatan manajemen mutu sistem pendidikan tinggi Islam bagi PTKIN di Indonesia perlu juga mengkombinasikan ISO 9001:2008 dengan pendekatan triple quality yang dikembangkan oleh Juran, yang terkenal dengan konsep Juran's Trilogy, ${ }^{19}$ yang mencakup 3 komponen utama, yaitu;

1. Quality Planning (perencanaan mutu). Perencanaan mutu merupakan tahapan untuk menentukan dan merancang segala perangkat pendidikan tinggi, baik infrastruktur maupun lainnya seperti misi, visi, program, kebijakan, serta sketsa tahapan proses yang akan dilalui untuk dirancang secara lebih matang dan komprehensif agar mampu menghasilkan pendidikan tinggi Islam yang lebih kompetitif dan produktif berdasarkan nilai-nilai keislaman sebagai landasan aplikasinya. Aspek quality planning menjadi penting dilakukan karena perkembangan PTKIN pada dasarnya juga menyesuaikan diri dari perkembangan masyarakat termasuk masyarakat global. Dengan kata lain, kebijakan yang dirancang adalah manifestasi dari kebutuhan dan keinginan masyarakat (social need and desire).

2. Quality Control (pengendalian mutu). Tahapan ini juga penting karena pengendalian mutu pada dasarnya merupakan jaminan mutu yang ingin dihasilkan. Dengan adanya quality control, PTKIN dapat memastikan proses implementasi manajemen pendidikan tingginya dapat berjalan secara efektif dan efisien sesuai dengan perencanaan semula, baik menyangkut program pendidikan yang dijalankan, kurikulum, perangkat infrastruktur pendidikan tinggi, SDM, out put yang dirancang, maupun tingkat akselerasinya terhadap kompetisi dunia pendidikan tinggi dan dunia kerja agar tetap eksis dan survive.

${ }^{19}$ Edward Sallis, Manajemen Kualitas Total Dalam Pendidikan (Total Quality Managementin Education), hlm. 67-68. 


\section{Jurnal Ilmiah Sustainable}

Vo. 1. No. 1, Juni 2018, 75-92

3. Quality Improvement (peningkatan mutu). Tahapan ini merupakan upaya tindak lanjut dari proses pelaksanaan mutu di mana seluruh rencana akademis PTKIN yang telah dilaksanakan dievaluasi untuk kemudian dilakukan pembenahan secara simultan dan komprehensif guna memperbaiki kelemahan yang terjadi sebelumnya. Dengan peningkatan mutu berkelanjutan, eksistensi PTKIN di Indonesia akan lebih appreciable terhadap kebutuhan dan perkembangan masyarakat global. Hal ini juga dapat diartikan bahwa pengelolaan program pendidikan tinggi Islam dalam konteks internasionalisasi pendidikan sudah saatnya memperhitungkan standar mutu sebagai basis peningkatan akselerasi equality access untuk bersaing berbagai tingkat kompetisi.

Dalam konteks demikian, menurut Hasyim Asy'ari, ${ }^{20}$ penerapan ISO 9001:2008 haruslah dilandasi oleh beberapa alasan. Pertama, penerapan ISO 9001:2008 membantu banyak hal terutama pembenahan manajerial di PTKIN.Kedua,tuntutan dan harapan masyarakat yang tinggi terhadap mutu lulusan; dan tantangan dunia pendidikan tinggi apalagi yang berlabel agama memang sangat berat. Ide untuk menghasilkan output yang bermutupatutlah mendapat dukungan semua pihak. Penerapan ISO 9001:2008 mendorong pimpinan untuk konsisten dengan klausul dan mekanisme PDCA, sehingga institusi memahami apa yang seharusnya dilakukan.

Sebagai sebuah contoh penerapan ISO 9001:2008 di UIN Maliki Malang. Secara garis besar klausul ISO 9001:2008 yang diterapkan oleh UIN Malang mencakup persyaratan umum dan dokumen; management responsibility, resource management, product realization (good, service), dan measurement, analysis and improvement. Penerapan klausul-klausul tersebutmerupakan fakta empirik dan menjadi satu mata rantai sekaligus menjadi satu kesatuan untuk upaya-upaya peningkatan mutu institusi. Salah satu klausul yang sudah diterapkan dengan baik adalah klausul fokus pada pelanggan. Inti dari klausul ini adalah adanya perhatian yang serius terkait pemenuhan kepuasan pelanggan.

\footnotetext{
${ }^{20}$ Hasyim Asy'ari, “Perbandingan Sistem Manajemen Mutu ISO 9001:2008, Standard BAN-PT dan Total Quality Management di UIN Maulana Malik Ibrahim Malang", hlm. 152-153. 89
} 


\section{Jurnal Ilmiah Sustainable}

Vo. 1. No. 1, Juni 2018, 75-92

Para pimpinan, dosen dan staf UIN Maliki Malang dalam hal ini selalu berusaha memberikan layanan terbaik untuk customer dengan menyediakan seluruh fasilitas yang dibutuhkan dalam proses pembelajaran, seperti LCD, hotspot/internet, layanan online, ruang kerja untuk Unit Kegiatan Mahasiswa (UKM), pendidikan model ma'had, pembenahan struktur serta penyediaan SDM yang memadai. Hal ini penting dilakukan dalam kerangka membangun motivasi belajar, motivasi berprestasi dan kinerja civitas akademika baik akademik maupun non akademik. Fokus pada pelanggan merupakan kunci dalam membangun loyalitas mahasiswa dan masyarakat serta stakeholder lain. Fokus pada pelanggan juga berdampak pada terbentuknya citra kampus yang positif sekaligus untuk membangun dukungan untuk menuju World Class University. Salah satu hal yang menarik di UIN Maliki Malang adalah tradisi pemanfaatan taman sebagai tempat belajar yang mungkin bagi kampus lain merupakan hal aneh.

Tradisi ini bermakna positif untuk menghilangkan kejenuhan mahasiswa dalam proses pembelajaran, sekaligus efisiensi tempat. Yang terpenting adalah tradisi ini tidak mengurangi makna belajar bagi mahasiswa. Realisasi Standar Pelayanan Minimal (SPM) penerapan ISO 9001:2008 mampu merubah dan mendorong kinerja institusi UIN Maliki Malang. Sebagai contoh dalam hal ini adalah rata-rata kehadiran dosen untuk semua fakultas menunjukkan angka yang tinggi yakni 90,39\%. Salah satu aspek penting penerapan ISO 9001:2008 adalah mendorong institusi untuk memberikan layanan pendidikan terbaik. $^{21}$

\section{Simpulan}

Berdasarkan keseluruhan uraian di atas dapat disimpulkan bahwa meningkatkan sumber daya manusia (SDM) Indonesia yang berkualitas merupakan suatu keniscayaan agar mampu menghadapi tantangan di era Revolusi Industri 4.0. Satu-satu cara untuk meningkatkan kualitas SDM itu adalah melalui pendidikan, khususnya lembaga pendidikan tinggi, termasuk di dalamnya Perguruan Tinggi Keagamaan Islam Negeri (PTKIN).

\footnotetext{
${ }^{21}$ lbid., hlm. 153-154.
} 


\section{Jurnal Ilmiah Sustainable}

Vo. 1. No. 1, Juni 2018, 75-92

Upaya meningkatkan kualitas PTKIN adalah melalui SNI ISO 9001:2008 sebagai salah satu manajemen mutu yang berprinsip pada TQM yang dalam penerapannya mendetail dan sistematis. Sistem ISO 9001:2008 merupakan sarana atau alat PTKIN untuk mencapai tujuan mutu yang diharapkan dan mampu menjawab tantangan era Revolusi Industri 4.0 saat ini. Selain itu, didalamya terdapat keharusan pengawasan mutu internal secara periodik (internal quality audit).Pada saat ini ISO 9001:2008 menjadi pilihan utama bagi lembaga pendidikan tinggi, PTKINuntuk menerapkan sistem manajemen mutu secara konsisten dan sistematisuntuk tercapainya efektivitas dan efesiensi

Dengan demikian penerapan ISO 9001:2008 di PTKIN sangatlah penting sebagai sebuah langkah untuk mewujudkan dan memberikan tata kelola yangbaik, meraih praktik pendidikan yang prima, meningkatkan kepuasan pelanggandan memberikan respon yang lebih baik pada kebutuhan industri. Motif utama yang dimiliki oleh PTKIN untuk menerapkan ISO 9001:2008 adalah sebagai langkah promosi untuk memberikan gambaran bahwa PTKIN memiliki mutu tinggi, visibilitas yang tinggi dan kredibilitas, respon pada faktor eksternaldan untuk mengembangkan sistem manajemen mutu secara keseluruhan, sehingga dapat memberikan layanan dan output terbaik yang dapat menjamin kepuasan seluruh customer,stakeholder, dan membantu pengelolaan mutu PTKIN yang ideal.

\section{DAFTAR PUSTAKA}

Azyumardi Azra, Paradigma Baru Pendidikan Nasional, Rekonstruksi dan Demokratisasi,(Jakarta: Penerbit Buku Kompas,2000)

Bunyamin dan Alamsyah, "Manajemen Mutu Perguruan Tinggi Agama Islam Swasta". Dalam Jurnal Pendidikan Islam, Vol 28, No 2, (Bandung: UIN Sunan Gunung Djati,2013)

Edward Sallis, Manajemen Kualitas Total Dalam Pendidikan (Total Quality Managementin Education), Terj. Kambey Daniel C., (Manado: Program Pascasarjana Universitas Negeri Manado, 2001)

Gaspersz, V., Manajemen Bisnis Total Dalam Era Globalisasi. (Jakarta:Gramedia Pustaka Utama, 2002). 


\section{Jurnal Ilmiah Sustainable}

Vo. 1. No. 1, Juni 2018, 75-92

Hasyim Asy'ari, “Perbandingan Sistem Manajemen Mutu ISO 9001:2008, Standard BAN-PT dan Total Quality Management di UIN Maulana Malik Ibrahim Malang". Dalam Jurnal Pendidikan Islam, Volume IV, Nomor 1, Juni, (Yogyakarta: UIN Sunan Kalijaga, 2015)

James Ward, Reclaining International Mindset of Education in Global Era. (USAWard: Penguin Book, 2000)

Othman, R, et.al.. ISO Standard Implementation at Private Colleged:Academics and Non Academics Perspective. The 1st InternationalConference on Educational Reform, November 9-11, (MahasarakhamUniversity, 2007).

Safrudin Aziz, Manajemen Mutu Perguruan Tinggi, Koreksi dan Implementasi, (Yogyakarta: Gava Media, 2016)

Sugeng Listyo Prabowo. Implementasi Sistem Manajemen Mutu ISO 9001:2008 di Perguruan Tinggi (Guidelines IWA-2). (Malang: UIN-Malang Press, 2009)

Umiyati, "Pengaruh Sistem Manajemen Mutu ISO 9001:2008 dan Partisipasi Penyusunan Anggaran Terhadap Kinerja Manajerial". Dalam Jurnal Etikonomi Vol. 14 No. 1 April, (Jakarta: Fakultas Ekonomi dan Bisnis, UIN Syarif Hidayatullah, 2015)

Wawan Setyawan. Prinsip Dasar ISO 9001:2008. (Jakarta: Universitas Mercu Buana, 2009).

"Menristekdikti: Persaingan Global di Era Revolusi Industri 4.0 Semakin Ketat". Lihat https://www.ristekdikti.go.id/menristekdikti-persaingan-global-diera-revolusi-industri-4-0-semakin-ketat-2/\#xdZjTrHYQmA2QPe7.99 $\quad\{21$ Mei 2018, 08:20 WIB\}

"Universitas Islam Negeri". Dalam https://id.wikipedia.org/wiki/ Universitas_Islam_Negeri. $\{20$ Mei 2018, 09:01 WIB\} 